\title{
Faktor-Faktor yang Mempengaruhi Kriminalitas di Indonesia Tahun 2011-2016 dengan Regresi Data Panel
}

\author{
Kosmaryati ${ }^{1}$, Chandra Arinda Handayani ${ }^{2}$, Refinanda Nur Isfahani ${ }^{3}$, Edy Widodo ${ }^{4}$ \\ ${ }_{1,2,3,4}$ Program Studi Statistika Fakultas MIPA UII, Yogyakarta \\ 15611144@students.uii.ac.id, edy.widodo@uii.ac.id.
}

\begin{abstract}
Criminality in Indonesia is increasing every year, therefore an effort is needed to reduce criminality in Indonesia, one of which can be used by knowing which factors influence the increase of criminality. This paper discusses the factors that influence criminality by using panel data regression analysis. Unemployment, domestic violence cases, narcotics cases, embezzlement cases, and fraud cases have positive effect on the amount of criminality with $R^{2}$ of 0,85823 or $85,823 \%$.
\end{abstract}

Keywords : panel regression analysis, crime, Indonesia

\section{Pendahuluan}

Kejadian kriminalitas di Indonesia sedang marak terjadi, dapat dengan mudah ditemukannya berita mengenai kriminalitas di berbagai media. Badan Pusat Statistik (BPS) memaparkan bahwa selama periode tahun 2014-2016 jumlah kejadian kriminalitas atau tindak kejahatan di Indonesia cenderung mengalami peningkatan [1]. Kriminalitas adalah segala sesuatu perbuatan dimana masyarakat menentangnya karena melanggar hukum dan norma-norma sosial, dan menimbulkan kerugian baik dari segi materi maupun psikologis [2]. Menurut Abdulsyani [3] kasus kriminalitas terjadi disebabkan oleh berbagai faktor, baik dari internal maupun eksternal. Misalnya tingkat pendidikan yang didapatkan, gaji atau upah yang tidak mencukupi, dan hubungan keluarga.

Salah satu metode yang digunakan untuk menganalisis suatu hubungan antar fenomena ekonomi yaitu analisis regresi. Penelitian mengenai pengaruh hubungan ekonomi khususnya pada tingkat kasus kriminalitas sering menggunakan analisis regresi spasial, keterkaitan secara spasial antar wilayah perlu diperhatikan karena berkaitan dengan suatu lokasi atau wilayah. Penelitian dengan menggunakan analisis regresi dengan pendekatan spasial sudah pernah dilakukan sebelumnya oleh Dona dan Setiawan [4] untuk memodelkan faktor-faktor yang mempengaruhi tingkat kriminalitas di Jawa Timur, dan penelitian yang dilakukan Ahmar dan Adiatama [5] dengan pemodelan kriminalitas dengan pendekatan regresi spasial di Provinsi Sulawesi Selatan.

Dalam melakukan suatu pengamatan terhadap sebuah fenomena atau peristiwa, tidak cukup hanya melakukan pengamatan tersebut terhadap unit-unit amatan dalam satu waktu tertentu saja, tetapi juga mengamati unit-unit tersebut pada berbagai periode waktu. 
Analisis regresi data panel adalah salah satu pendekatan pemodelan yang mengikutsertakan pengaruh waktu tersebut ke dalam model. Selain itu, pemodelan data panel secara umum akan memberikan informasi yang lebih informatif dibandingkan pemodelan yang hanya menggunakan data lintas individu (cross section) atau data deret waktu (time series) saja [6]. Data panel sendiri merupakan data gabungan antara data lintas individu dan deret waktu.

Maka untuk itu peneliti tertarik mengangkat tema mengenai jumlah kriminalitas di Indonesia untuk mengetahui bagaimana pengaruh dari variabel upah minimum provinsi (UMP), jumlah pengangguran, jumlah penduduk miskin, IPM, PDRB, kasus KDRT, kasus narkotika, kasus penggelapan, dan kasus penipuan. Hal ini agar dapat memberikan informasi alternatif kepada instansi terkait untuk mengatasi masalah kriminalitas (jumlah kasus kriminalitas). Dimana pada penelitian ini digunakan metode analisis regresi data panel untuk mengetahui faktor yang berpengaruh terhadap kriminalitas di Indonesia.

\section{Tinjauan Pustaka}

\subsection{Model Data Panel}

Menurut Basuki dan Yuliadi [7], terdapat tiga metode pendekatan yang dapat dilakukan untuk mengestimasi model regresi dengan data panel yaitu model gabungan, model pengaruh tetap, dan model pengaruh acak. Model panel pengaruh gabungan (common effect), persamaan modelnya sama dengan regresi linier biasa yaitu:

$$
Y_{i t}=\beta_{0}+\sum_{j=1}^{k} \beta_{j} X_{j i t}+\varepsilon_{i t}
$$

Persamaan model panel pengaruh tetap (fixed effect) sebagai berikut:

$$
Y_{i t}=\beta_{0}+\sum_{j=1}^{k} \beta_{j} X_{j i t}+\mu_{i}+\varepsilon_{i t}
$$

Sedangkan, persamaan model panel pengaruh acak (random effect) :

$$
Y_{i t}=\beta_{0 i}+\sum_{j=1}^{k} \beta_{j} X_{j i t}+\varepsilon_{i t}
$$

$\operatorname{dimana} \beta_{0 i}=\beta_{0}+\mu_{i}$.

\subsection{Uji Chow}

Uji Chow merupakan uji signifikansi untuk menentukan apakah menggunakan model gabungan atau model pengaruh tetap. Hipotesis awal $\left(H_{0}\right)$ pada uji Chow adalah tidak terdapat pengaruh individu terhadap model (model mengikuti model gabungan) dan hipotesis tandingannya $\left(H_{l}\right)$ adalah terdapat satu atau lebih pengaruh individu terhadap model (model mengikuti model pengaruh tetap). 
Statistik uji yang digunakan adalah :

$$
F_{0}=\frac{(R R S S-U R S S) /(N-1)}{U R S S /(N T-N-K)}
$$

dimana restricted residual sums of square (RRSS) diperoleh dari jumlah kuadrat galat hasil pendugaan model gabungan dan unrestricted residual sums of square (URSS) diperoleh dari jumlah kuadrat galat hasil pendugaan model pengaruh tetap. Keputusan tolak $\mathrm{H}_{0}$ jika $F_{0}>F N-1, N(T-1)-K$ atau jika nilai $p<\alpha[8]$.

\subsection{Uji Hausman}

Uji Hausman digunakan untuk menguji signifikansi antara model pengaruh acak dengan model pengaruh tetap. Secara hipotesis bahwa pada suatu populasi, jika individu diambil secara acak sebagai contoh maka dugaan model data panel adalah model pengaruh acak, namun bila individu yang digunakan merupakan keseluruhan individu dari populasi tersebut maka cenderung menggunakan model pengaruh tetap. Hipotesis awal $\left(H_{0}\right)$ yang digunakan pada uji ini adalah model mengikuti model pengaruh acak dan hipotesis tandingannya $\left(H_{1}\right)$ adalah model mengikuti model pengaruh tetap. Statistik uji yang digunakan adalah

$$
\begin{gathered}
\chi^{2}=\hat{q}[\operatorname{Var}(\hat{q})]^{-1} \widehat{q} \\
\hat{q}=\widehat{\beta}_{\text {acak }}-\widehat{\beta}_{\text {tetap }}
\end{gathered}
$$

dengan $\widehat{\beta}_{\text {acak }}$ adalah vektor koefisien peubah penjelas dari model pengaruh acak dan $\widehat{\beta}_{\text {tetap }}$ adalah vektor koefisien peubah penjelas dari model pengaruh tetap. Keputusan tolak $H_{0}$ jika $\chi^{2}>\chi_{k, \alpha}^{2}$ dengan $k$ merupakan banyaknya peubah penjelas atau tolak $H_{0}$ jika nilai $p<\alpha[8]$.

\subsection{Uji Lagrange Multiplier}

Menurut Widarjono [9], Lagrange multiplier (LM) digunakan untuk menguji apakah model random effect lebih baik dari model common effect. Hasil dari hipotesis uji LM adalah sebagai berikut:

\section{$H_{0}$ : commont effect}

$$
H_{1} \text { : random effect }
$$

\subsection{Uji Breusch Pagan}

Menurut Rosadi [10], uji Breusch Pagan digunakan untuk menguji apakah terdapat efek waktu, individu atau keduanya dengan hipotesis sebagai berikut: 
$H_{0}^{(1)}$ : Tidak ada efek individu dan waktu

$H_{I}{ }^{(1)}$ : Ada efek individu dan waktu

$H_{0}^{(2)}$ : Tidak ada efek lintas individu

$H_{I}{ }^{(2)}$ : Ada efek lintas individu

$H_{0}{ }^{(3)}$ : Tidak ada efek waktu

$H_{I}^{(3)}$ : Ada efek waktu

Keputusan tolak $H_{0}$ jika nilai $p$ kurang dari taraf signifikansi $\alpha$ yang ditentukan.

\subsection{Uji Asumsi}

Menurut Gujarati dan Porter [11], metode estimasi model panel pengaruh acak (random effect) menggunakan metode generalized least square (GLS), sedangkan model panel pengaruh gabungan (common effect) dan model panel pengaruh tetap (fixed effect) menggunakan ordinary least square (OLS). Salah satu kelebihan metode GLS yaitu tidak perlu memenuhi asumsi klasik. Jadi, apabila model regresi menggunakan random effect maka tidak perlu dilakukan uji asumsi klasik. Sebaliknya, apabila digunakan model regresi common effect atau fixed effect maka perlu dilakukan uji asumsi klasik. Menurut Gujarati dan Porter [12] sangat kecil kemungkinan terjadi multikolinearitas pada data panel sehingga peneliti cukup melakukan uji autokorelasi dan uji heterokedastisitas.

\subsection{Uji Hipotesis}

Menurut Nachrowi dan Usman [13], untuk menguji signifikansi koefisien regresi dapat menggunakan uji hipotesis. Terdapat dua uji hipotesis digunakan untuk menguji koefisien regresi yaitu, uji simultan (uji $F$ ) dan uji parsal (uji $t$ ). Uji $F$ ini dilakukan untuk mengetahui apakah model regresi yang diestimasi dapat dikatakan layak atau tidak. Uji ini dikatakan uji $F$, karena mengikuti distribusi $F$ dalam kriteria pengujian itu seperti one way anova. Untuk menentukan layak atau tidaknya model regresi yaitu dengan membandingkan nilai $F$ hitung dengan $F$ tabel, dimana rumus $F$ hitung yang digunakan sebagai berikut [14]:

$$
\text { F hitung }=\frac{R^{2} /(k-1)}{\left(1-R^{2}\right) /(n-k)}
$$

Uji statistik $t$ ini dilakukan untuk mengetahui pengaruh variabel independen terhadap variabel dependen (seberapa besar variabel dependen dapat diterangkan oleh variabel independen secara individual). Uji $t$ dapat dilakukan dengan menggunakan rumus sebagai berikut : 


$$
t=\frac{\beta_{\mathrm{i}}}{\operatorname{Se}\left(\beta_{\mathrm{i}}\right)}
$$

dengan $\beta i$ merupakan koefisien regresi $\operatorname{ke} i$ dan $\operatorname{Se}\left(\beta_{\mathrm{i}}\right)$ adalah standar eror koefisien regresi.

\subsection{Koefisien Determinasi}

Koefisien determinasi merupakan suatu ukuran untuk menghitung seberapa jauh kemampuan model regresi dalam menerangkan variasi variabel dependen. Berikut rumus untuk menghitung koefisiensi determinasi [15].

$$
R^{2}=\frac{n\left(a \sum Y+b_{1}-\sum Y X_{1}+b_{2} \sum X Y_{2}-\left(\sum Y\right)^{2}\right)}{n\left(\sum Y^{2}-\left(\sum Y\right)^{2}\right)}
$$

\section{Hasil dan Pembahasan}

Data yang digunakan dalam penelitian ini adalah data sekunder yang menggabungkan antara data cross section yaitu provinsi di Indonesia dan data time series tahun 2011 sampai 2016. Data diperoleh dari BPS, data tenaga kerja dan transmigrasi dan bank Indonesia tahun 2011 sampai 2016. Variabel dependen yang digunakan dalam penelitian ini adalah variabel jumlah kriminalitas, sedangkan variabel independen yang digunakan adalah UMP, jumlah pengangguran, jumlah penduduk miskin, IPM, PDRB, kasus KDRT, kasus narkotika, kasus penggelapan, dan kasus penipuan.

\subsection{Statistika Deskriptif}

Tahapan awal dalam penelitian ini yaitu melakukan analisis deskriptif, untuk mengetahui gambaran umum mengenai jumlah kriminalitas yang terjadi di Indonesia tahun 2011-2016.

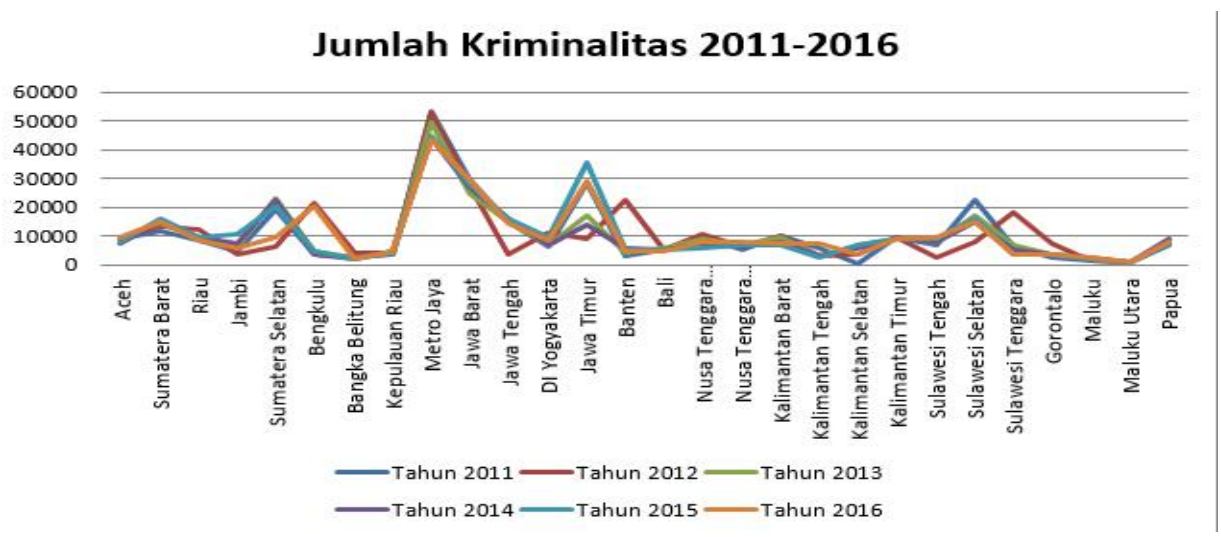

Gambar 1. Grafik Jumlah Kriminalitas tahun 2011-2016 
Berdasarkan Gambar 1, tingkat kriminlitas paling tinggi terjadi di Metro Jaya dari tahun 2011 hingga 2016. Untuk tahun 2011 tingkat kejahatan terendah ditempati oleh provinsi Kalimantan Selatan, kemudian di tahun 2012 hingga 2016 tingkat kriminalitas terendah ditempati oleh provinsi Maluku Utara.

\subsection{Uji Chow}

Uji Chow digunakan untuk menentukan apakah model regresi data panel menggunakan common effect model atau fixed effect model, maka hipotesisnya sebagai berikut:

$$
\begin{aligned}
& \mathrm{H}_{0} \text { : common effect model } \\
& \mathrm{H}_{1} \text { : fixed effect model }
\end{aligned}
$$

Berdasarkan uji chow, diperoleh nilai $p$ yaitu 2.622e-10. Jika dibandingkan dengan nilai $\alpha(0,05)$ maka $H_{0}$ ditolak karena nilai $p<\alpha$. Dari hasil uji Chow maka model yang sesuai atau model yang terpilih adalah fixed effect model.

\subsection{Uji Hausman}

Pengujian statistik untuk memilih apakah model yang digunakan adalah random effect model atau fixed effect model menggunakan uji Hausman. Hasil dari pengujian ini adalah mengetahui metode mana yang sebaiknya dipilih. Dalam pengujiannya hipotesis sebagai berikut:

\section{$H_{0}$ : Random effect model \\ $H_{1}$ : Fixed effect model}

Berdasarkan hasil uji Hausman pada Gambar 1, diperoleh nilai $p$ yaitu 0,9352. Jika dibandingkan dengan nilai $\alpha(0,05)$ maka $H_{0}$ ditolak karena nilai $p<\alpha$. Dari hasil uji Hausman maka model yang terpilih adalah random effect model. Uji Lagrange multiplier tidak dilakukan karena pada uji Hausman diperoleh model yang terbaik yaitu random effect model.

\subsection{Uji Breusch Pagan}

Uji Breusch Pagan yaitu untuk mengetahui efek apa yang akan digunakan pada model. Pada interpretasi model terbaik ini terdapat tiga pilihan model efek yaitu efek dua arah (two ways), efek individual dan efek waktu (time).

Dari uji Breusch Pagan pada Tabel 1 didapat bahwa untuk efek two ways dan individual signifikan dan untuk efek time tidak signifikan, sehingga dapat disimpulkan bahwa model menggunakkan efek individual. 


\subsection{Uji Simultan (Uji $F)$}

\begin{tabular}{cc}
\multicolumn{2}{c}{ Tabel 1. Uji Breusch Pagan } \\
\hline Effect test & Nilai $\boldsymbol{p}$ \\
\hline Two ways & 0,012 \\
Individual & 0,006219 \\
Time & 0,2436
\end{tabular}

Uji simultan (uji $F$ ) digunakan untuk mengetahui apakah seluruh variabel independen mempengaruhi variabel dependen.

$H_{0}: \beta_{1}=\beta_{2}=0$ (Seluruh variabel independen tidak berpengaruh terhadap variabel dependen)

$H_{1}$ : Paling tidak terdapat satu $\beta_{0} \neq 0$ (Paling tidak terdapat satu variabel independen berpengaruh terhadap variabel dependen).

Berdasarkan hasil uji simultan diperoleh nilai $p$ yaitu 2.22e-16. Jika dibandingkan dengan nilai $\alpha(0,05)$ maka $H_{0}$ ditolak karena nilai $p<\alpha$. Dari hasil uji simultan maka variabel UMP, jumlah pengangguran, jumlah penduduk miskin, IPM dan perceraian secara keseluruhan berpengaruh terhadap jumlah kriminallitas.

\subsection{Uji Parsial (Uji $t)$}

Kemudian uji parsial digunakan untuk mengetahui apakah setiap variabel independen berpengaruh terhadap variabel dependen.

$H_{0}: \beta_{i}=0 \quad$ (Tidak terdapat pengaruh variabel independen terhadap variabel dependen )

$H_{1}: \beta_{i} \neq 0 \quad$ (Terdapat pengaruh variabel independen terhadap variabel dependen)

Berdasarkan hasil uji parsial pada Tabel 2 diketahui bahwa variabel UMP, jumlah pengangguran, jumlah penduduk miskin, IPM, PDRB dan intercept tidak signifikan terhadap variabel dependen, maka dilakukan proses penghilangan variabel satu per satu dengan nilai $p$ terbesar.

Tabel 2. Uji parsial

\begin{tabular}{ll}
\hline Variabel & Nilai $\boldsymbol{p}$ \\
\hline Intercept & 0,876452 \\
UMP & 0,141612 \\
Jumlah pengangguran & 0,069329 \\
Jumlah penduduk miskin & 0,370749 \\
IPM & 0,782601 \\
PDRB & 0,918583 \\
KDRT & 0,000626 \\
Narkotika & $3,641 \mathrm{e}-05$ \\
Penggelapan & 0,000278 \\
Penipuan & $2,127 \mathrm{e}-07$ \\
\hline
\end{tabular}


Tabel 3. Uji Parsial dengan penghapusan variabel yang tidak signifikan

\begin{tabular}{lcccc}
\multicolumn{1}{c}{ Variabel } & $\begin{array}{c}\text { Nilai } \boldsymbol{p} \\
\text { Tahap 1 }\end{array}$ & $\begin{array}{c}\text { Nilai } \boldsymbol{p} \\
\text { Tahap 2 }\end{array}$ & $\begin{array}{c}\text { Nilai } \boldsymbol{p} \\
\text { Tahap 3 }\end{array}$ & $\begin{array}{c}\text { Nilai } \boldsymbol{p} \\
\text { Tahap 4 }\end{array}$ \\
\hline Intercept & 0,829 & 0,006 & 0,010 & 0,004 \\
UMP & 0,126 & 0,125 & 0,190 & \\
Jumlah pengangguran & 0,065 & 0,060 & 0,039 & 0,013 \\
Jumlah penduduk miskin & 0,366 & 0,339 & & \\
IPM & 0,805 & & & \\
KDRT & 0,0005 & 0,0002 & 0,0002 & 0,0005 \\
Narkotika & $2,978 \mathrm{e}-05$ & $2,279 \mathrm{e}-05$ & $3,380 \mathrm{e}-05$ & $7,318 \mathrm{e}-05$ \\
Penggelapan & 0,0002 & 0,0001 & $4,982 \mathrm{e}-05$ & $2,741 \mathrm{e}-05$ \\
Penipuan & $1,304 \mathrm{e}-07$ & $4,670 \mathrm{e}-09$ & $1,283 \mathrm{e}-11$ & $3,398 \mathrm{e}-12$ \\
\hline
\end{tabular}

Berdasarkan Tabel 3 hasil uji parsial tahap 4 diketahui bahwa seluruh variabel independen berpengaruh terhadap variabel dependen.

Dari hasil output diperoleh nilai R-Squared sebesar 0,85823 atau 85,823\%. Hal tersebut artinya variabel jumlah pengangguran, narkotika (kasus penyalahgunaan NAPZA), kasus KDRT, kasus penggelapan, dan kasus penipuan mampu menjelaskan variabel jumlah kriminalitas dan sisanya 14,177\% dijelaskan variabel lain diluar model.

\subsection{Uji Asumsi}

Karena hasil model yang didapatkan adalah random effect maka tidak dilakukan uji asumsi klasik karena model random effect merupakan metode estimasi generalized least square (GLS). Teknik GLS dipercaya mengatasi adanya autokorelasi runtun waktu (time series) serta korelasi antar observasi (cross section). Metode GLS menghasilkan estimator untuk memenuhi sifat best linier unbiased estimation (BLUE) yang merupakan metode treatment untuk mengatasi pelanggaran asumsi homoskedastisitas dan autokorelasi.

\subsection{Interpretasi Model Terbaik}

Selanjutnya adalah interpretasi model terbaik dengan model terbaik yang didapatkan adalah random effect model dengan effect individual.

Tabel 4. Koefisien Regresi/Slope

\begin{tabular}{cc}
\hline Variabel & Slope \\
\hline Jumlah pengangguran & 0,0023691 \\
KDRT & 6,9541 \\
Narkotika & 1,4350 \\
Penggelapan & 2,7017 \\
Penipuan & 3,8147 \\
\hline
\end{tabular}


Dari hasil interpretasi model terbaik didapatkan nilai slope, maka didapat persamaan regresi data panel sebagai berikut:

$$
\widehat{y}_{i}=\widehat{\beta}_{0 i t}+0,0023691 X_{1 i i}+6,9541 X_{2 i i}+1,4350 X_{3 i i}+2,7017_{4 i i}+3,8147 X_{5 i i}
$$

dengan

$\widehat{y}_{i} \quad:$ kabupaten/ kota ke- $i$

$\widehat{\beta}_{0 i t} \quad$ : nilai intersep setiap provinsi (individu)

$X_{\text {lit }} \quad$ : jumlah pengangguran provinsi ke- $i$

$X_{2 i t} \quad$ :jumlah kasus KDRT provinsi ke- $i$

$X_{3 i t} \quad$ :jumlah kasus narkotika provinsi ke- $i$

$X_{4 i t} \quad$ :jumlah kasus penggelapan provinsi ke- $i$

$X_{\text {sit }} \quad$ :jumlah kasus penipuan provinsi ke- $i$

Berdasarkan persamaan model regresi data panel yang diperoleh ini menyatakan bahwa bentuk hubungan berbanding lurus yang berarti setiap peningkatan satu jumlah pengangguran maka akan memberikan dampak kenaikan 0,0023691 pada jumlah kriminalitas, begitu pula dengan kasus KDRT, kasus narkotika, penggelapan, dan penipuan.

Selanjutnya adalah untuk mengetahui besar nilai yang pengaruh dari masingmasing objek individu, berikut merupakan hasil dari nilai intercept setiap objek individu.

Dari pengujian random effect didapat nilai intercept dari setiap individu, nilai tersebut merupakan nilai error data setiap individu dan nilai efek inividu. 
Tabel 5.Nilai Intercept Setiap Individu

\begin{tabular}{cccc}
\hline Individu & Nilai intercept & Individu & Nilai intercept \\
\hline Aceh & $-47375,91$ & Kepulauan Riau & $-45643,08$ \\
Bali & $-48475,65$ & Maluku & $-45678,76$ \\
Bangka Belitung & $-44203,31$ & Maluku Utara & $-43865,78$ \\
Banten & $-46963,28$ & Metro Jaya & $-41659,39$ \\
Bengkulu & $-40128,48$ & Nusa Tenggara Barat & $-42880,48$ \\
DI Yogyakarta & $-51156,66$ & Nusa Tenggara & $-43322,17$ \\
Gorontalo & $-43603,73$ & Timur & $-34846,83$ \\
Jambi & $-44467,73$ & Papua & $-43725,06$ \\
Jawa Barat & $-58496,84$ & Riau & $-45040,82$ \\
Jawa Tengah & $-57084,36$ & Sulawesi Selatan & $-45191,42$ \\
Jawa Timur & $-50762,52$ & Sulawesi Tenggara & $-44020,60$ \\
Kalimantan Barat & $-41934,25$ & Sumatera Barat & $-43285,30$ \\
Kalimantan Selatan & $-44431,27$ & Sumatera Selatan & $-43854,39$ \\
Kalimantan Tengah & $-42529,99$ & Kalimantan Timur & $-40987,65$ \\
\hline
\end{tabular}

\section{Kesimpulan}

Berdasarkan analisis yang telah dilakukan maka didapatkan beberapa kesimpulan antara lain sebagai berikut :

1. Dari hasil uji regresi data panel dengan model acak efek individu didapat persamaan umum sebagai berikut:

$\widehat{y}_{i}=\widehat{\beta}_{0 i t}+0,0023691 X_{1 i t}+6,9541 X_{2 i t}+1,4350 X_{3 i t}+2,7017_{4 i t}+3,8147 X_{5 i t}$

2. Berdasarkan persamaan model regresi data panel yang diperoleh ini menyatakan bahwa variabel jumlah pengangguran, kasus KDRT, kasus narkotika, kasus penggelapan, dan kasus penipuan berpengaruh positif terhadap jumlah kriminalitas.

\section{Daftar Pustaka}

[1] Suhariyanto. Statistik Kriminal 2017. Badan Pusat Statistik Indonesia, Katalog: 4401002. Jakarta. 2017.

[2] Kartono. Patologi Sosial. Raja grafindo Persada. Jakarta. 1999.

[3] Abdulsyani. Sosiologi kriminalitas. Penerbit Remadja Karya CV. Bandung. 1987.

[4] Dona dan Setiawan. Pemodelan faktor-faktor yang mempengaruhi tingkat kriminalitas di Jawa Timur dengan analisis Regresi Spasial. Sains dan Seni. Jurnal Sains Dan Seni ITS. 4 (1): D73-D78. 2015.

[5] Ahmar, Ansari Saleh dan Adiatama. Pemodelan Kriminalitas dengan Pendekatan Regresi Spasial di provinsi Sulawesi Selatan. Prosiding Seminar Nasional VARIANSI. 2015. 
[6] Elhorst. Spatial Panel Data Models, In Handbook of Applied Spatial Analysis. Springer. New York. 2010.

[7] Basuki, Agustri dan Imamudin Yuliadi. Elektronik Data Prosesing (SPSS 15 dan EVIEWS 7). Danisa Media. Yogyakarta. ISBN : 979-602-7577-31-2. 2014.

[8] Baltagi. Econometrics Analysis of Panel Data Third Edition. John Wiley \& Sons. England. 2005.

[9] Widarjono, A. Ekonometrika Teori dan Aplikasi Untuk Ekonomi dan Bisnis (2nd ed). Ekonisia FE UII. Yogyakarta. 2007.

[10] Rosadi, D. Ekonometrika dan Analisis Runtun Waktu Terapan dengan R. C. V. Andi Offset. Yogyakarta. 2011.

[11] Gujarati, D dan Porter, D. Dasar-Dasar Ekonometrika (Terjemahan). Salemba Empat. Jakarta. 2009.

[12] Gujarati, D dan Porter, D. Dasar-Dasar Ekonometrika (Terjemahan), Edisi Lima, Buku Dua. Penerbit Salemba Empat. Jakarta. 2012.

[13] Nachrowi dan Usman. Pendekatan Populer dan Praktis Ekonometrika untuk Analisis Ekonomi dan Keuangan. Lembaga Penerbit FE UI. Jakarta. 2006.

[14] Prasetyo, Adit Agus. Analisis Faktor-faktor yang Mempengaruhi Tingkat Kemiskinan:Studi Kasus 35 Kabupaten Kota di Jawa Tengah tahun 2003-2007. Skripsi, Universitas Diponegoro. Semarang. 2010.

[15] Wahid, Sulaiman. Analisis-Analisis Regresi menggunakan SPSS. ANDI. Yogyakarta. 2004. 